\title{
Leptomeningeal Metastasis in a Breast Cancer Treated with Two Lines of Intrathecal Chemotherapy - a Case Report
}

\section{Leptomeningeálne metastázy karcinómu prsníka liečené dvoma líniami intratekálnej chemoterapie - kazuistika}

\author{
Mikudova V. ${ }^{1,2}$, Rejlekova K. ${ }^{1}$, Gyarfas J. ${ }^{2,3}$, Oravcova I. ${ }^{2}$, Chovanec M. ${ }^{1}$, Mardiak J. ${ }^{1}$, Mego M. \\ 12nd Department of Oncology, Faculty of Medicine, Comenius University, National Cancer Institute, Bratislava \\ ${ }^{2}$ Oncohematology Clinic, Faculty of Medicine, Comenius University, National Cancer Institute, Bratislava \\ ${ }^{3}$ Department of Hematology, National Cancer Institute, Bratislava
}

\begin{abstract}
Summary
Background: Leptomeningeal metastasis (LM) in breast cancer is associated with a poor prognosis. Although no randomised trial has demonstrated that intrathecal chemotherapy actually prolongs survival, this treatment is considered standard of care in this setting. The prognosis of patients with LM is poor, with a median overall survival time of less than 6 months. Methods: Herein, we report a case of a young woman with breast cancer who presented with LM at the time of relapse and was subsequently treated with two lines of intrathecal chemotherapy that prolonged survival. Results: A 28-year old woman without a significant past medical history was diagnosed with triple-negative invasive ductal carcinoma. Eight months after adjuvant treatment she developed multiple brain metastases and LM developed subsequently 1 month after finishing whole brain irradiation. Initially, she was treated with a combination of methotrexate, cytarabine and dexamethasone intrathecally but after 3 months she presented with a worsening clinical status and increased numbers of cancer cells in cerebrospinal fluid. Subsequently, she received a combination of thiotepa and methotrexate intrathecally, which resulted in a prolonged response lasting 10 months. The patient died 32 months after initial diagnosis and 18 months from LM infiltration due to disease progression in the liver and lungs as well as LM. Conclusion: The prognosis of patients with LM remains poor because of the limited effectiveness of currently available therapies; however, intrathecal chemotherapy could substantially prolong survival in selected patients.
\end{abstract}

Key words

leptomeningeal metastasis - breast cancer - intrathecal treatment - thiotepa
The authors declare they have no potential conflicts of interest concerning drugs, products, or services used in the study.

Autoři deklarují, že $v$ souvislosti s predmětem studie nemaji žádné komerční zájmy.

The Editorial Board declares that the manuscript met the ICMJE recommendation for biomedical papers.

Redakční rada potvrzuje, že rukopis práce splnil ICMJE kritéria pro publikace zasílané do biomedicínských časopisů.

prof. Michal Mego, M.D., DrSc. $2^{\text {nd }}$ Department of Oncology Faculty of Medicine Comenius University National Cancer Institute Klenova 1

83310 Bratislava, Slovak Republic e-mail:misomego@gmail.com

Submitted/Obdržané: 7. 11.2018 Accepted/Prijaté: 29. 11. 2018

doi: 10.14735/amko2018139 


\begin{abstract}
Súhrn
Východiská: Leptomeningeálne metastázy (LM) karcinómu prsníka sú asociované s nepriaznivou prognózou. Hoci žiadna randomizovaná štúdia nepotvrdila, že intratekálna liečba predlžuje prežívanie, táto liečba je považovaná za štandard. Prognóza pacientov s LM je nepriaznivá, s mediánom celkového prežívania menej ako 6 mesiacov. Metódy: $V$ tejto kazuistike uvádzame prípad mladej ženy s karcinómom prsníka s LM $v$ čase recidívy, liečenej dvoma líniami intratekálnej chemoterapie s predíženým prežívaním. Výsledky: Dvadsatosemročnej žene bez pozoruhodnej anamnézy bol diagnostikovaný triple-negatívny invazívny duktálny karcinóm. Osem mesiacov po adjuvantnej terapii sa rozvinuli mnohopočetné mozgové metastázy a následne 1 mesiac po ukončení rádioterapie na centrálny nervový systém sa vyvinuli nové LM. Iniciálne bola liečená kombináciou metotrexát, cytarabín a dexametazón intratekálne, ale po 3 mesiacoch u pacientky došlo k zhoršeniu klinického stavu a vzostupu nádorových buniek v likvore. Následne dostala kombináciu tiotepy a metotrexátu intratekálne s predížením odpovede v trvaní 10 mesiacov. Pacientka zomrela 32 mesiacov od stanovenia diagnózy a 18 mesiacov od infiltrácie leptomenigov v dôsledku progresie ochorenia v pečeni a plúcach ako aj v leptomeningoch. Záver: Prognóza pacientov s LM zostáva nepriaznivá v dôsledku limitovanej účinnosti súčasne dostupných látok používaných v intratekálnej liečbe, avšak intratekálna chemoterapia by mohla podstatne predížit prežívanie u vybraných pacientov.
\end{abstract}

\title{
Klúčové slová
}

leptomeningeálne metastázy - karcinóm prsníka - intratekálna liečba - tiotepa

\section{Introduction}

Leptomeningeal metastasis (LM) is defined as the spread of tumor cells within the leptomeninges and the subarachnoid space. LM may be diagnosed in approximately $10 \%$ of patients with metastatic cancer in the course of disease [1]. The incidence is probably underestimated because of non-specific symptoms and signs, lack of sensitivity to diagnostic procedures and limited therapeutic options. Breast cancer (BC), lung cancer and melanoma represent the three most common causes of LM. Patients with lobular subtype and triplenegative tumors have a relatively higher risk of $L M$ than with other types of $B C$ [2].

Herein, we report a case of a young woman with $\mathrm{BC}$ who presented with
LM at the time of relapse and who was subsequently treated with two lines of intrathecal chemotherapy (CHT) with prolonged survival.

\section{Case report}

A 28-year old woman without significant past medical history presented with a 2-month history of painless resistance in the left breast. In June 2015, breast ultrasound showed hypoechoic lesion measuring $26 \times 19 \mathrm{~mm}$ with associated axillary lymphadenopathy. Core-cut biopsy set the diagnosis of triple-negative invasive ductal carcinoma. A staging computed tomography (CT) scan confirmed no metastatic dissemination. In July 2015, subcutaneous mastectomy and axillary dissection were performed

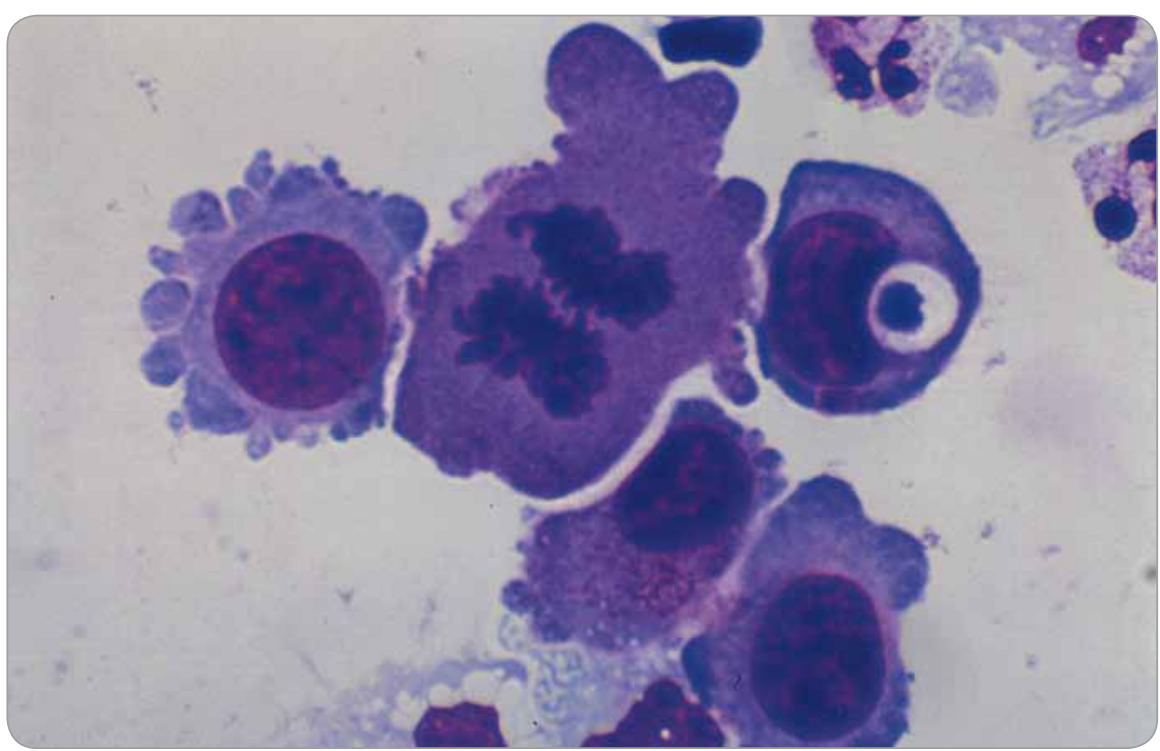

Fig. 1. Cytology in cerebrospinal fluid.

and concluded as stage pT2pN3M0. The patient was treated with four cycles of dose-dense CHT doxorubicin/cyclophosphamide plus paclitaxel and then with adjuvant radiotherapy (RT) on the chest wall and axilla until December 2015.

In August 2016, the patient was admitted with headache and paraneoplastic syndrome of inappropriate antidiuretic hormone secretion. Cerebral CT and magnetic resonance imaging (MRI) revealed multifocal brain metastases. A restaging $C T$ showed no metastatic dissemination in other parenchymal organs. She received whole brain RT with total dose of $30 \mathrm{~Gy}$. Subsequently, shewas readmitted with meningeal syndrome (headache, photosensitivity, rigidity of the occipital muscles) in October 2016. Cerebrospinal MRI confirmed regression of intraparenchymal metastases, but cerebrospinal fluid (CSF) cytology confirmed leptomeningeal infiltration with BC cells $\left(0.232 \times 10^{9} / \mathrm{L}\right)$ (Fig. 1). For the intrathecal treatment, we used standard dosing of $15 \mathrm{mg}$ methotrexate (MTX), $40 \mathrm{mg}$ cytarabine and $4 \mathrm{mg}$ dexamethasone (DXM) (total of 10 doses, twice a week) and irradiation of spinal cord until December 2016 with clinical improvement and disappearance of symptoms of meningeal irritation. At the time of dismissal, there was persistence of sphincter disorder and mild pain of lumbosacral spine and decrease of cancer cells in CSF to $0.022 \times 10^{9} / \mathrm{L}$.

In January 2017, the patient presented with worsening of clinical status (ce- 
phalea, nausea and vomiting). The lumbar puncture was performed with increase of cancer cells $\left(0.094 \times 10^{9} / \mathrm{L}\right)$ and elevated proteinorachia $(1664 \mathrm{mg} / \mathrm{L}$, normal range is $150-300 \mathrm{mg} / \mathrm{L})$. The restaging $\mathrm{CT}$ confirmed multiple metastases in the liver. After two doses of intrathecal treatment (MTX, cytarabine and DXM), we identified elevated count of cancer elements in CSF $\left(0.143 \times 10^{9} / \mathrm{L}\right)$; therefore, we decided for administration of thiotepa and MTX in $2^{\text {nd }}$ line. From February until November 2017, 28 doses of $10 \mathrm{mg}$ thiotepa, $10 \mathrm{mg}$ MTX and $4 \mathrm{mg}$ DXM were administered concurrently with systemic CHT (paclitaxel $80 \mathrm{mg} / \mathrm{sqm}$ biweekly) due to the metastatic disease in the liver and lungs. In CSF, we observed a decrease of elements already after 3 doses of intrathecal treatment (Graph 1). The last cytomorphology of CSF from November 2017 was clear.

In January 2018, the patient was admitted with paraplegia and pleural effusion gradually with disorder of consciousness. The CT scan confirmed progression of liver and lung metastases. In a consideration of poor performance status, there was no indication for an aggressive approach. The patient died 32 months after initial diagnosis and 18 months after LM infiltration due to disease progression.

\section{Discussion}

LM is becoming an increasingly common complication in patients with BC. Moreover, prognosis of patients with LM is poor. There is no standardized therapy for LM because of a lack of randomized trials. The median overall survival (OS) of patients after LM diagnosis does not exceed 6 months [3]. The factors associated with increased survival are Karnofsky performance score $\geq 70$, age $>53$, luminal biological subtype of $\mathrm{BC}(\mathrm{ER}+\mathrm{PR}+\mathrm{HER} 2-)$, systemic therapy, intrathecal therapy and RT [4].

Although no randomized trial has demonstrated that intrathecal CHT prolongs survival in LM patients, intrathecal pharmacotherapy is considered standard of treatment across the world. Four agents are commonly used for the intrathecal treatment of LM -

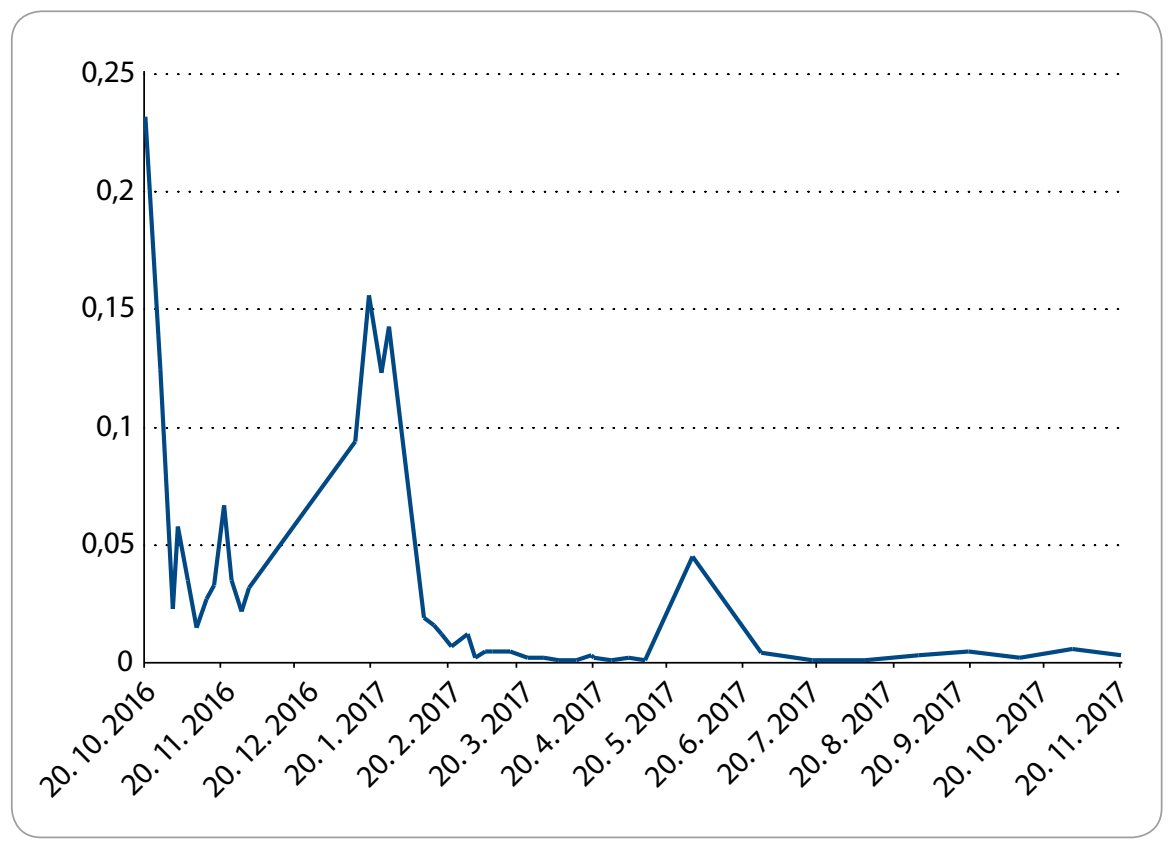

Graph 1. Kinetics of cancer cells in cerebrospinal fluid (10\%/L).

MTX, cytarabine, including liposomal cytarabine, thiotepa and trastuzumab for HER2 positive BC with LM $[5,6]$. No intrathecal agent has shown a significant survival advantage over another. Toxicities of the various intrathecal agents differed. More mucositis or neurological complications such as headache were observed with MTX than with thiotepa [7]. Similarly to MTX, thiotepa functions as a myelosuppressive agent and therefore should not be used in patients with bone marrow disorders.

There is no specific treatment of $L M$ based on molecular subtype of $B C$, with the exception of trastuzumab in HER2 positive subtype. In our case, we considered thiotepa as a cell cyclenonspecific alkylating agent based on activity of alkylating agents in the triple-negative BC [8]. Niwińska et al. [9] in their prospective observational study compared the efficacy of MTX and liposomal cytarabine in patients treated intrathecally. Among treatment methods, only systemic therapy prolonged survival in patients with LM. Neither RT nor lumbar intrathecal therapy influenced survival in those patients; however, both methods alleviated signs and symptoms of LM. No difference in survival was observed in patients treated intrathecally with MTX and those treated with liposomal cytarabine. Treatment with both drugs was comparable. Boogerd et al. [10] in a randomized study concluded that the addition of intrathecal MTX to standard systemic $\mathrm{CHT}$ and RT did not lead to a survival benefit, improved neurologic response in LM patients, but was associated with a substantially increased risk of neurotoxicity. The study by Grossman et al. [7] randomized patients with LM from any solid tumor primary to MTX or thiotepa. Of 52 patients, 25 had BC. The median OS was similar in both treatment arms (15.9 vs. 14.1 weeks). Their results suggested that in patients with LM, no significant difference in median survival or serious toxicity resulted from the use of MTX vs. thiotepa.

Some studies are in progress to expand the drugs for intrathecal $\mathrm{CHT}$ to include drugs, such as trastuzumab, for treatment of LM in patients with HER2positive $B C$ [6]. It was shown that patients with LM show notably high levels of vascular endothelial growth factor (VEGF) in the CSF, which are associated with the poor prognosis. Chen et al. [11] examined the effect of combined systemic therapy of bevacizumab with etoposide and cisplatin in two patients who showed disease progression after 
whole brain RT and intrathecal therapy. Results of this study showed decreased leptomeningeal enhancement, disappearance of cancer cells in CSF. A study by Wu et al. [12] examined the efficacy of this chemotherapeutic regimen in patients with BC and LM. After excluding patients who received previous VEGF-targeted therapies and including patients who received concomitant intrathecal MTX therapy, median OS was 4.7 months and central nervous system response rate $70 \%$.

\section{Conclusion}

Prognosis of patients with LM remains poor because of the limited effectiveness of the currently available agents used in intrathecal therapies. The future studies should focus on developing targeted and cytotoxic drugs showing improved bloodbrain barrier penetration that may provide a therapeutic advantage in patients with LM. Although there is no consensus on the treatment of LM, division of $B C$ patients according to the different subtypes could help in administering subtype-specific treatments. This is supported by the differential treatment response of patients with different $B C$ subtypes without LM.

\section{References}

1. Chamberlain M, Junck L, Brandsma D et al. Leptomeningeal metastases: a RANO proposal for response crite ria. Neuro Oncol 2017; 19(4): 484-492. doi: 10.1093/neuonc/now183.

2. Abouharb S, Ensor J, Loghin ME et al. Leptomeningeal disease and breast cancer: the importance of tumour subtype. Breast Cancer Res Treat 2014; 146(3): 477-486. doi: 10.1007/s10549-014-3054-z.

3. Rudnicka H, Niwińska A, Murawska M. Breast cancer leptomeningeal metastasis - the role of multimodality treatment. J Neurooncol 2007; 84(1): 57-62. doi: 10.1007/ s1 1060-007-9340-4.

4. Niwińska A, Pogoda K, Michalski W et al. Determinants of prolonged survival for breast cancer patient groups with leptomeningeal metastasis (LM). J Neurooncol 2018; 138(1): 191-198. doi: 10.1007/s11060-018-2 790-z.

5. Le Rhun E, Weller M, Brandsma D et al. EANO-ESMO clinical practice guidelines for diagnosis, treatment and follow-up of patients with leptomeningeal metastasis from solid tumours. Annal Oncol 2017; 28 (Suppl 4): iv84-iv99. doi: 10.1093/annonc/mdx221.

6. Mego M, Sycova-Mila Z, Obertova J et al. Intrathecal administration of trastuzumab with cytarabine and methotrexate in breast cancer patients with leptomenin- geal carcinomatosis. Breast 2011; 20(5): 478-480. doi: 10.1016/j.breast.2011.05.007.

7. Grossman SA, Finkelstein DM, Ruckdeschek JC et al. Randomized prospective comparison of intraventricular methotrexate and thiotepa in patients with previously untreated neoplastic meningitis. Eastern Cooperative Oncology Group. J Clin Oncol 1993; 11(3): 561-569. doi: 10.1200/JCO.1993.11.3.561

8. Sharma P, López-Tarruella S, García-Saenz JA et al. Pathological response and survival in triple-negative breast cancer following neoadjuvant carboplatin plus docetaxel. Clin Cancer Res 2018; 24(23): 5820-5829. doi: 10.1158/1078-0432.CCR-18-0585.

9. Niwińska A, Rudnicka H, Murawska M. Breast cancer leptomeningeal metastasis: the results of combined treatment and the comparison of methotrexate and liposomal cytarabine as intra-cerebrospinal fluid chemotherapy. Clin Breast Cancer 2015; 15(1): 66-72. doi: 10.1016/j. clbc.2014.07.004.

10. Boogerd W, van den Bent MJ, Koehler PJ et al. The relevance of intraventricular chemotherapy for leptomeningeal metastasis in breast cancer: a randomised study. Eur J Cancer 2004; 40: 2726-2733. doi: 10.1016/j. ejca.2004.08.012.

11. Chen IC, Lin CH, Jan IS et al. Bevacizumab might potentiate the chemotherapeutic effect in breast cancer patients with leptomeningeal carcinomatosis. J Formos Med Assoc 2016; 115(4): 243-248. doi: 10.1016/ j.ffma.2015.03.005

12. Wu PF, Lin CH, Kuo CH et al. A pilot study of bevacizumab combined with etoposide and cisplatin in breast cancer patients with leptomeningeal carcinomatosis.BMCCancer2015;15:299.doi:10.1186/s12885-0151290-1. 